Meta

Journal des tradlucteurs

Translators' Journal

\title{
Considerations for the Craft of Translation
}

\section{Mariana Mould de Pease}

Volume 35, numéro 3, septembre 1990

La traduction dans le monde hispanolusophone

URI : https://id.erudit.org/iderudit/002536ar

DOI : https://doi.org/10.7202/002536ar

Aller au sommaire du numéro

Éditeur(s)

Les Presses de l'Université de Montréal

ISSN

0026-0452 (imprimé)

1492-1421 (numérique)

Découvrir la revue

Citer cet article

Mould de Pease, M. (1990). Considerations for the Craft of Translation. Meta, 35(3), 494-498. https://doi.org/10.7202/002536ar d'utilisation que vous pouvez consulter en ligne.

https://apropos.erudit.org/fr/usagers/politique-dutilisation/ 


\title{
CONSIDERATIONS FOR THE CRAFT OF TRANSLATION*
}

\author{
Mariana Mould de Pease \\ Lima, Perú
}

\begin{abstract}
It has been my desire in this paper to share with translators some of the trials, tribulations and difficult renderings $I$ have encountered while practising the craft of translation. The aim is not to discourage but to encourage those in the field to translate more works from English into Spanish, since it is important to Peruvians to understand how English speakers perceive their culture.

I consider it necessary to call attention to the urgent need for translations into Spanish of Peruvianist works since the gap of what is known in English and that which is translated grows greater every year. This gap is not lessened by conferences for several reasons. The first is that conferences of specialists on Peru take place out of the country and rarely have a Peruvian member. Secondly, foreign specialists and Peruvians often find it difficult to communicate even on the same subject because of deep intercultural differences. Therefore, we who practice translation should assume as our professional responsibility the reducing of the information gap and the promoting of intercultural understanding between Peruvians and Peruvianists.
\end{abstract}

In recent years there has been some discussion among Peruvian translators about the craft of translation. There should be more discourse of this type that specifically relates to Peruvianist research published in English. These works, both highly specialized and for the general public, were originally written for English-speaking readers. There are also several books written by 19th-century French of German scholars on Peru that were promptly translated into English, but still await a Spanish version ${ }^{1}$. All these works are especially important to Peruvians since they have a great relevance and impact in the understanding of what Peru and Peruvians are, but they are only available to a select group of Peruvians who know English.

Over the years, there has been some attempts to translate foreign works into Spanish. During the Colonial period Peru was very isolated from works by Englishspeaking authors, and it was not until the beginning of the 19th century that contact between the countries was initiated. In 1868, Federico Elmore, a British sailor living in Lima, urged that translations be made into Spanish of books of English-speaking travelers who had journeyed through Peru. He stated that these works should be translated in Peru so they could be widely known to Peruvians ${ }^{2}$. Manuel Beltroy, in 1920, expressed his concern for the paucity of works translated into Spanish in his introduction to the Spanish version of The Incas of Peru ${ }^{3}$.

As we can see, the efforts to close the gap in the translation of Peruvianist studies have been consistent, but they have fallen short ${ }^{4}$. The persons that assumed the task of translation came from different backgrounds and had diverse motivations. Starting with Nemesio Fernandez Cuesta who came from a family of Spanish translators and who translated W. Prescott's The History of the Conquest of Peru $(1848)^{5}$ to the present-day example of the University of the Pacific (Lima, Peru) that assumes the responsibility for the translation of all the Peruvianist works that it publishes. Since this diversity of approaches to translation renders diverse results, it is necessary to be aware of how and to 
what extent these translations fulfill their goal; that is, making available to Spanish speakers works written in English on Peru.

At no other time have Peruvians been more prepared to promote a specialization of professional translators. Translators are now being trained and many have already graduated from the Feminine University of the Sacred Heart and Ricardo Palma University in Lima. Most of these translators are women who have already translated and published books and articles on history, anthropology, archaeology, sociology and economics in Peru.

\section{TIHE PROCESS OF TRANSLATION}

In writing this article I am drawing on my own experience and presenting various methods, techniques and hazards encountered while practicing the craft of translation.

Before beginning their task, professional translators should be aware that working in a team, with the author and/or a specialist in the field, is the best way to insure a reliable version of their work. Once the team is set up the first step is for the translator to prepare a basic version in Spanish. Next, this version is revised with the author and/or specialist to verify the terminology and the cultural nuances. The translator should then do an overall and meticulous revision of the text prior to preparing the final version. This is a process, then, that requires very special motivation, dedication and skill to obtain an optimum version.

After the translation is completed, there remains yet another step, since eventually all translators have to introduce themselves to the complex editorial world. I, as a Peruvian, am aware that the Peruvian publishing industry doesn't have the necessary economic resources to finance all the translations. Therefore, it is fortunate that some of the Peruvianists are providing funding for the Spanish translation and publishing of their own works.

In short, the translation and publishing of Peruvianist works goes far beyond the translator's study. So we, as translators, should assume as part of our task the responsibility to conciliate the process of translation with its publication. Certainly, each represents the two worlds that we are trying to bring together through our work.

\section{PROBLEMS IN TRANSLATING}

To translate the works of the Peruvianists written in English, we as translators have to be aware that the work is the culmination of a long process. To begin with, most Peruvianist works are partially based on documents and/or oral communication in Spanish. The author, writing in English, may or may not have total command of this language. The translators' task is then to put the ideas of the foreign researcher into good Spanish. Therefore, the craft of translation consists of making a book written in English, based mainly on data in Spanish, elaborated through research methods developed by and for the English-speaking culture, into a comprehensive and familiar text for the Spanishspeaking reader.

The following illustrations, arising from my experience as a translator, elucidate some of the problems of translating Peruvianist works. The first is a good example of the vicissitudes that a book in translation has to go through to be published.

One of the first books that I translated was The Men of Cajamarca by the American historian James Lockhart (1972), which recently appeared in my Spanish version under the title Los de Cajamarca (1987). The publisher, Carlos Milla Batres, requested that I translate the book by early 1977. A year later, January 30, 1978, Dr. Lockhart wrote to him: "In short, I am sending you the whole translation in three parts; one part revised for the first time and two parts for the second, all of it approved with the only condition that 
no changes be made without presenting them to me so I can revise them again. In letters addressed to you and the translator, I talked extensively on everything related to the translation". It took Carlos Milla Batres ten years to publish this book which is fundamental to understanding the conquest of Peru. However, the delay wasn't due to the reasons he adduces in the preface, that there were serious problems with the translation. The truth is that he had serious problems directly related to the printing of the book. In my opinion, the publisher made such a statement, although he knew it wasn't true, because he found it easier to use the traditional excuse of blaming the delay on the translator. Cases such as this should be made public so that translators can defend themselves 6 .

The situations encountered in the second example could also be useful to other translators. This case concerns James Lockhart's book Spanish Peru, 1532-1560: A Colonial Society. This work was published by the University of Wisconsin-Madison Press in 1968 and was based on his Ph.D. dissertation. My Spanish version, El Mundo Hispano-Peruano, 1532-1560 was published in 1982. First, it is important to note that I suggested the translation and both the author and the publisher, The Fund of Economic Culture, Mexico City, accepted it. The FEC has a long and productive tradition promoting Spanish versions of universal books, and they were quite concerned that the book in Spanish resemble the American edition. Nevertheless, they neglected to reproduce the seven illustrations included in the original edition. Apparently, it is almost impossible to reproduce an exact version of a work and this made me aware that this is one of the situations that the translator can't control. In the second place, work was made easier this time for several reasons. Since I had already translated the author's other book on Peru, I knew him personally and had benefited from his intercultural understanding. Also, his style of writing was familiar to me. I knew that he is very knowledgeable on 16th-century Spanish idioms and I knew that he wanted them present in the Spanish version of his book. Finally, the author didn't have time to carefully revise the translation since he had broadened his approach on Latin America and wasn't specifically researching the conquest of Peru. So rendering into Spanish Dr. Lockhart's interpretation of the first thirty years of Hispanic life in Peru was my entire responsibility.

When I started translating Spanish Peru, I had in mind that the author had carefully introduced the English-speaking reader to the Hispanic-Peruvian 16th-century vocabulary. In doing so, he included in his writings several Spanish terms, for example:

"Silversmith or platero was the name the Spaniards gave not only to silversmiths but to goldsmiths, jewelers..." (p. 104).

To preserve this in Spanish, I translated this as:

"Los españoles llamaban plateros no solo a los que trabajaban la plata sino tambien a los que trabajaban el oro, a los joyeros..." (p. 135).

Though I am aware that his explanation is unnecessary for the Spanish-speaking reader, to have eliminated it would have changed the concept of the book itself.

The vocabulary examples, some from printed chronicles and others from unpublished documents, and the way the author dealt with them are numerous and various. Sometimes he quoted these words in Spanish, but in some cases he translated them into English. In the latter cases, I had to render them back to the Spanish original. When doing this I checked both the chronicles and with Peruvian specialists so that the Spanish version would have the idioms used in the 16th century. An excellent example of this was the word 'grant' which required diverse renderings. In a certain context 'grant' translated as merced, a 16th-century term, while in others it was donación, concesión, otorgamiento, which are all Spanish terms in present day usage. 
In looking back at the translation, I find that having translated 'indian' as indígena consistently through both books is no longer satisfactory to me. My argument then was: if I translated indian as indigena, the Spanish version wouldn't have the prejudices which are inherent in the other option, the word indio. Both options were possible since in Peruvian Spanish both words are used as synonyms. Even though the author approved it, I now think that in using indigena instead of indio, the translation lost some of its 16thcentury flavor.

The third example that I wish to use is the Peruvian edition of La oligarquia en el Perú: historia de tres familias by Dennis Gilbert (1982). This translation, due to the personal interest of the author, is the result of our teamwork. First, I prepared a draft. Next, Dr. Gilbert and I, with a Peruvian version in mind, discussed and analyzed the different possibilities of translation until both of us agreed on the final version.

Although the Peruvian edition faithfully represents the author's ideas, it differs in some aspects from the original work. For example, the original version states:

"In 1921, he and Manuel [Jorge and Manuel Prado] had gone into hiding to avoid being thrown into prison. That same year Javier [Prado] committed suicide."

Now, through Limenian oral tradition I knew that there were several versions of how Javier Prado passed away. The author accepted that the version in Spanish would read:

"En 1921, el y Manuel [Jorge and Manuel Prado] tuvieron que esconderse para evitar ser encarcelados. Ese mismo año murió Javier [Prado]." (p.162)

These changes were possible because they were approved by the author. When his book was published, Dr. Gilbert specified that he wanted my name as translator to appear on the front page. The publisher insisted that my name go on the following page since he was convinced that the book would not sell if it was evident that it was a translation. This then is yet another example of the publisher putting the translator into a secondary position. Regardless of what publishers may think, I believe that a translator should receive credit for his / her work.

For a final example, we will look at a case of institutional collaboration with the translator. In this case, the book is by Fritz Wils published in 1975 from his Ph.D. dissertation as Industrialists, Industrialization and the Nation State in Peru. The translation was published by the Catholic University, Peru, some four years later as Los industriales, la industrialización y el estado nación en el Perú. This book is based mainly on a survey consisting of interviews and questionnaires presented to industrialists in the Lima-Callao area. These questionnaires were designed by Dr. Wils and modified by a group of Peruvian student-assistants who participated in his seminar on comparative industrialization. What was of particular interest to translators in this case was the frequent use of idiomatic expressions which always pose a challenge. The following is a brief selection of the terms and phrases used by the author and how these were rendered into Spanish.

1. Our understanding of reality is all too often of the armchair variety, making little allowance for its complexity (p. ix).

Nuestra comprensión de la realidad está frecuentemente bastante alejada del trato directo con los problemas, haciendo poca concesión a su complejidad (p. 4).

2. This state of affairs was both a consequence of, and a condition for, a very limited redistribution of power, wealth and income - all the more serious in a country with a limited internal market (p. 14).

Esta situación fue tanto consecuencia, como una condición para una redistribución muy limitada del poder, de las riquezas e ingresos - de especial trascendencia en un país con un mercado nacional limitado (p. 36). 
3. References abound to lack of achievement motivation, to distrust, machismo, huachafería, dignidad, hyperbolic individualism, familismo and so on (p. 113).

Abundan las referencias sobre la falta de motivación hacia el logro, la desconfianza, el machismo $(x)$, la huachafería $(x)$, la dignidad $(x)$, el individualismo hiberbolico, el familismo $(\mathrm{x}), \mathrm{y}$ demas rasgos afines. $(\mathrm{x})$ in Spanish in the original. Later on, when the author used familism as an English word, I translated this as dependencias familiares (pp. 116, 156).

4. First a brief comment of the bed fellows, particularly on the pro-military side (p. 211).

Primero, un breve comentario sobre los compañeros de viaje, especialmente en el lado favorable a los militares (p. 281).

5. Industrial growth as a happening (p. 22).

El crecimiento industrial como suceso (p. 45).

6. Tidal waves vs. concurrence of foreign and national investments? (p. 64).

¿El vaiven frente a la concurrencia de inversiones extranjeras y nacionales? (p. 96).

* This article is a synthesis of my presentations in the Round Table "Translation and its Hinders" and the Seminar "Towards the Praxis of Translation from English into Spanish and Viceversa" that were organized by the Binational Center Peru-USA in September 1985 and January 1986. I want to express my sincere gratitude to Dr. Carol Mackey for improving my English.

\section{NOTES}

1. TSCHUDI, J.J. (1854): Travels in Peru, translation from German by Tomasina Ross, New York, A.S. Barnel. MARCOY, Paul (1872): A Journal across South America, Blackie and Son, London, 4 vols.

2. Letter to E.G. Squier, Lima, June 13, 1868. Library of Congress, Washington, D.C.

3. MARKHAM, Sir Clements R. (1920): Los Incas del Perú, Spanish version by Manuel Beltroy, Foreword, xii, Lima.

4. BELAUNDE, Víctor Andrès (1908): El Perú antiguo y los modernos sociólogos, Lima: 13.

5. MOULD DE PEASE, Mariana (1985): "La historia del Perú en traducción: un comentario a las primeras versiones en español de la obra de William H. Prescoti", Historica, vol. IX, no. 1: 15-34.

6. MOULD DE PEASE, Mariana (1987): "La historia del Perú en traducción: Un testimonio personal", $E l$ Comercio, Sunday Supplement, Nov, 22, Lima. 